\title{
DESCRIPTION OF A NEW MOTH OF THE GENUS
} PHYLLODES.

\author{
By A. Sidney Olliff, F.E.S., \\ Assistant Zoologist, Australian Museum.
}

The genus Phyllodes is chiefly interesting on account of the wonderful variation to which the markings are liable, a variation which is the more interesting as it appears to correspond to more or less definite geographical limits. In the form of the genus which occurs in the Andaman Islands, P. roseigera, Butl., there is a red patch on the hindwing touching the anal angle; in the Indian form, $P$. consobrina, Wtw., this patch has a conspicuous white centre; in the $P$. cerasifera, Butl., from Mindanao, the white is greatly increased in size and extends nearly to the inner edge of the red patch; in other forms the white leaves the red patch; and finally, in the Amboynese form, $P$. conspicillator, Cram., (see illustration), we find that the white appears to have travelled quite across the wing. Our Australian form, which is characterised below, continues in the same line of variation, the patch assuming a band-like appearance, and the whole extending itself along the hind-margin of the wing. This singular alteration in the position of the markings or colourpatches was first pointed out by Mr. A. G. Butler, who has adopted the term "chromatropy" to express this particular kind of variation, at the suggestion of Dr. F. Leuthner.*

As the early stages of Phyllodes do not appear to be known, it it to be hoped that observers in Queensland will give their attention to the subject. The transformations of several species of the

* Cf. Lepidoptera collected during the recent Expedition of H.M.S. 'Challenger.'-Ann. Mag. Nat. Hist, xi. (5) p. 427 (1883). 
the allied genus Ophideres have been described from information obtained in Java and elsewhere ; and I may add that a detailed life-history of O. salaminia, Cram., drawn up from observations made at Ash Island, in the Hunter River, is contained in the manuscript of the late Mr. A. W. Scott, the publication of which has recently been decided upon by the trustees of the Australian Museum, under the joint editorship of Mrs. E. Forde and myself.

\section{OPHIDERID $Æ$.}

\section{Phyllodes Meyricki, sp.n.}

Antennæ reddish-brown; head between the eyes and the palpi brownish-purple; thorax and abdomen reddish-brown, the latter faintly tinged with purple. Forewing rich reddish-brown, glossed with purple, the red increasing in intensity near the hind-margin, with a somewhat obscure patch of white on the costa at rather less than two-thirds from the base, a similar but even less distinet patch of white at the apex, and an indistinct brown line, edged with reddish, extending obliquely from the apex towards the middle of the wing, and reaching a point just before the stigma, about half-way between the costal and abdominal margins; the stigma greyish-brown, very conspicuous, enclosing two rich brown lines. Hindwing blue-black, inclining to brownish near the base, with a large rosy-pink fascia or band-like marking extending from the inner margin to beyond the middle of the wing, and provided with a row of seven or eight distinct white spots on the hind-margin. Underside coloured much as above, but with the ground colour duller, somewhat lighter, and less rich; the forewing from the base to beyond the middle dark red-brown, tinged with purple, with three white spots in the middle placed obliquely across the wing one behind the other, the last or hindmost being much smaller than the first and second which are large and conspicuous. Expanse of wings $160 \mathrm{~mm}$.; length of body $53 \mathrm{~mm}$.

Mount Bellenden-Ker, near Cairns, and Daintree River, Queensland. 
This species is most nearly related to Phyllodes conspicillator, Cram., * described from the island of Amboyna, but it differs so materially in markings from that species that I feel justified in proposing the name $P$. Meyricki for it, as it is now very generally admitted that the practice of distinguishing geographical forms under distinctive names is a good one.

Two specimens of this form are known to me; one from Mt. Bellenden-Ker, collected by Messrs. Cairn and Grant, has been in the collection of the Australian Museum for some time, and more recently a specimen from the Daintree River was forwarded by Mr. C. French to Dr. Ramsay, the Curator of that institution, at whose request I have drawn up the above description.

For the wood-engraving which accompanies this paper the Society is indebted to Mr. J. M. Cantle.

* The following is, I believe, a complete list of the old-world species of the geuus Phyllodes described up to this time.

Phyllodes semilinea, Walker, Journ. Linn. Soc. vii. p. 176 (1864). Borneo.

Ph. ornata, Moore, Desc. Lepid. Atkin. ii. p. 166 (1882). Darjiling.

Ph. ustulata, Westw., Cab. Or. Entom. p. 57, pl. 28, fig. 1 (1848). Darjiling.

Ph. Eyndhovii, Vollenh., Tijd. v. Ent. p. 86, pl. 6 (1858);=Ph. fasciata, Moore, P.Z.S. 1867, p. 69. Darjiling, Java.

Ph.roseigera, Butl., P.Z.S., 1883, p. 164 ; Ann. Mag. Nat. Hist. xi. (5), p. 427, fig. 1, hindwing (1883). Andaman Is.

Ph. maligna, Butl., Ent. Mo. Mag. xx. p. 138 (1883). Ceylon.

Ph. consobrina, Westw., Cab. Or. Entom. p. 57, pl. 28, fig. 2 (1848); Butl., Ann. Mag. Nat. Hist., xi. (5), p. 427, fig. 2, hindwing (1883). Silhet.

Ph.cerasifera, Butl., l.c., p. 426, fig 3, hindwing. Mindanao.

Ph. floralis, Butl., 1.c., p. 427, fig 4, hindwing: characters in key only. Borneo.

Ph. Verhuellii, Vollenh., Tijd.v. Entom p. 159 (1858); Butl., l.c., fig. 5, hindwing. Java.

\& Ph. conspicillator, Cramer, Pap. Exot. ii. pl. xevii. fig. A.B. (1779); Butl., l.c., fig. 6 , hindwing; $=\delta P h$. inspicillator, Guénée. Amboyna.

Ph. conspicillator, Cram., var. (perhaps a new species), Pag. J.B. nass. Ver. xxxix. p. 138 (1886). Aru Is. 


\section{$2 \mathrm{BHL}$ Biodiversity Heritage Library}

Olliff, Arthur Sidney. 1889. "Description of a new moth of the genus

Phyllodes." Proceedings of the Linnean Society of New South Wales 4, 113-116. https://doi.org/10.5962/bhl.part.15038.

View This Item Online: https://www.biodiversitylibrary.org/item/29780

DOI: https://doi.org/10.5962/bhl.part.15038

Permalink: https://www.biodiversitylibrary.org/partpdf/15038

\section{Holding Institution}

MBLWHOI Library

\section{Sponsored by}

MBLWHOI Library

\section{Copyright \& Reuse}

Copyright Status: NOT_IN_COPYRIGHT

This document was created from content at the Biodiversity Heritage Library, the world's largest open access digital library for biodiversity literature and archives. Visit BHL at https://www.biodiversitylibrary.org. 